\title{
DIETARY SUPPLEMENTATION OF VITAMIN E AND SELENIUM ALLEVIATE THE NEGATIVE EFFECTS OF HIGH STOKING DENSITY IN GROWING JAPANESE QUAIL
}

\author{
A. A. Desoky ${ }^{1}$ and Nancy N. Kamel ${ }^{2}$ \\ ${ }^{I}$ Department of Animal Production, Faculty of Agriculture, Cairo University, Egypt. \\ ${ }^{2}$ Department of Animal Production, National Research Center, Dokki, Giza, Egypt.
}

(Received 9/9/2018, accepted 16/10/2018)

\section{SUMMARY}

$\mathrm{I}$ n poultry intensive production system, stoking density is an inevitable practice. Thus, this study was designed to investigate the negative effects of high stoking density on quail growth performance, blood constituents and gut microbial count, and whether vitamin E and selenium supplementations have potential effects on enhancing the bird performance under high stoking density. A total of 225 Japanese quail at eight days of age were randomly allocated to five experimental groups (45 chicks each), with three replicates per group (15 chicks each). The groups formed low stoking control group $\left(80 \mathrm{birds} / \mathrm{m}^{2}\right)$ as the negative control (N-Control), the high stoking control group $\left(100 \mathrm{birds} / \mathrm{m}^{2}\right)$ as the positive control (P-Control), and three groups having high stoking density $\left(100 \mathrm{birds} / \mathrm{m}^{2}\right)$ and supplemented with either $200 \mathrm{mg}$ vitamin $\mathrm{E} / \mathrm{kg}$ diet or $0.3 \mathrm{mg}$ selenium $/ \mathrm{kg}$ diet or $100 \mathrm{mg}$ vitamin $\mathrm{E}$ and $0.15 \mathrm{mg}$ selenium $/ \mathrm{kg}$ diet. High stoking density negatively affected body weight gain and feed conversion ratio compared to the low stoking density. Blood calcium, phosphorus and tibia ash and tibia calcium decreased significantly with high stoking density. The supplementation of diet with vitamin $\mathrm{E}$ and selenium separately or combined, under high stoking density, improved quail body weight gain and feed conversion. Blood calcium and phosphorus levels and tibia calcium and phosphorus contents significantly increased with different diet supplementations compared to the non-supplemented high stoking density control. Vitamin $\mathrm{E}$ and selenium supplementations significantly reduced ileum total microbial count and E-coli count. The result revealed that high stoking density impaired quail performance, but vitamin $\mathrm{E}$ and selenium and their combination can be used to improve quail performance under intensive production system.

Keywords: Stoking density, quail, vitamin E, selenium, growth performance.

\section{INTRODUCTION}

Birds under different stress conditions suffer from oxidative stress and consequently the bird performance declines. Harsini et al. (2012) reported significant increases in antioxidant enzymes in both blood and skeleton muscles of broilers subjected to cyclic heat stress when the feed was supplemented with a combination of vitamin E and selenium. Attia et al. (2017) reported that vitamin E at $100 \mathrm{mg} / \mathrm{kg} \mathrm{diet} \mathrm{alleviate}$ the negative effect of heat stress on body weight gain and dressing percentage of broilers. The improvement in egg production was reported by Biswas et al. (2010) when vitamin E was supplemented to the feed of native chicken in India. Sahin et al. (2002) reported the improvement of egg production and egg quality in heat stressed quail fed diet supplemented with $250 \mathrm{mg}$ vitamin $\mathrm{E} / \mathrm{kg}$.

On the other hand, selenium is one of the important micronutrients in poultry diet that maintains antioxidant defenses when birds are under oxidative stress conditions (Surai, 2002; Fan et al., 2009; Habibian et al., 2015). Oliveira et al. (2014) recommended the supplementation of broiler diet by selenium at 0.15 $\mathrm{ppm} / \mathrm{kg}$ in order to maintain bird normal performance. Broiler viability under heat stress condition increased significantly with selenium supplementation at the level of $0.3 \mathrm{mg} / \mathrm{kg}$ diet (Albuquerque et al., 2017). In 


\section{Desoky and Kamel}

quail and during heat stress condition, egg production and antioxidant status improved significantly when diet was supplemented with organic-form selenium (Sahin et al., 2008). Vesco et al. (2017) reported a significant effect of selenium supplementation, at $0.33 \mathrm{mg} / \mathrm{kg}$ diet, on gene expression of natural antioxidant enzymes in quail reared under heat stress.

A synergistic effect of vitamin $\mathrm{E}$ and selenium was reported to improve the natural activities of antioxidant enzymes in the chicken superficial pectoralis muscle (Avanzo et al., 2001). Vitamin E and organic selenium supplementation improve the productivity and immune response of laying hen (Ziaei et al., 2013). Singh et al. (2006) also reported high immune response of broilers when feed was supplemented with $200 \mathrm{mg}$ vitamin E/kg and $0.2 \mathrm{mg}$ selenium $/ \mathrm{kg}$ diet. Sahin et al. (2003) recommended a combined supplementation of $250 \mathrm{mg}$ vitamin $\mathrm{E}$ and $0.2 \mathrm{mg}$ selenium $/ \mathrm{kg}$ diet in order to reduce the negative effects of cold stress on quail egg production and quality.

Early studies revealed positive relationship between high stoking density of broilers and profitability (Shanawany, 1988; Cravener et al., 1992). In this concern, significant reduction in body weight gain, feed intake, feed conversion and immune response were common negative effects of high stoking density in broiler chickens (Dozier et al., 2006; Abudabos et al., 2013a; El-Gogary et al., 2015; Qaid et al., 2016; Selvam et al., 2017). Also, egg production was impaired by high stoking density in laying hens (Asghar Saki et al., 2012; Jahanian and Mirfendereski, 2015; Mirfendereski and Jahanian 2015). Nagarajan et al. (1991) reported significant improvement in body weight gain, egg production and food conversion with the increase in cage space per laying hen. In Egypt, laying quail showed declines in fertility, hatchability, egg production, egg quality and immune response when reared under high stoking density $\left(143 \mathrm{~cm}^{2} /\right.$ bird $)$ compared to low stoking density $\left(200 \mathrm{~cm}^{2} / \mathrm{bird}\right)$ (EL-Tarabany et al., 2015; El-Tarabany, 2016). The various effects of high stoking density on quail meat production are not intensively studied.

The present study was designed to investigate the negative effects of high and low stoking density imposed on quail performance, blood metabolites and ileum bacterial count, and to investigate the potential effects of vitamin $\mathrm{E}$ and selenium dietary supplementation on elevating quail performance under high stoking density.

\section{MATERIALS AND METHODS}

\section{Management and experimental design:}

A total of 225 unsexed Japanese quail at eight days of age were randomly allocated to five experimental groups (45 chicks each) with three replicates (15 birds each) in each group. Each experimental group was assigned randomly to one of five treatments. Two groups were fed the basal diet (Table 1) and served as the negative and positive stoking density control with 80 and $100 \mathrm{birds} / \mathrm{m}^{2}$, respectively. The remaining three groups were fed the basal diet and assigned to one of the following diet supplementations: a diet supplemented with $200 \mathrm{mg}$ vitamin E/ $\mathrm{kg}$ (Vit E), a diet supplemented with $0.3 \mathrm{mg}$ selenium $/ \mathrm{kg}(\mathrm{Se})$, or a diet supplemented with $100 \mathrm{mg}$ vitamin E/kg and $0.15 \mathrm{mg}$ selenium/ $\mathrm{kg}$ (Vit E+Se) with a stoking density of 100 birds $/ \mathrm{m}^{2}$. Quail were reared in wired cages of $30 \times 50 \mathrm{~cm}^{2}$. The feed was offered ad libitum and fresh water was available at all time.

\section{Production and physiological parameters:}

Body weights were recorded at $8,21,35$ and 42 days of age and body weight gain was calculated for each group. Feed intake was recorded and feed conversion was calculated for each group.

At the end of the experiment, nine birds from each group were slaughtered and blood samples were collected in heparinized tube. Plasma was separated and stored at $-20{ }^{\circ} \mathrm{C}$ until further analysis. Plasma total protein, albumin, cholesterol, triglycerides, ALT, AST, calcium and phosphorus were measured using kits (Salucea, Haansberg, Netherlands). 
Table (1): Composition and calculated analysis of the basal diet (\%).

\begin{tabular}{|c|c|}
\hline Ingredients & $8-42$ days \\
\hline Yellow corn & 54.62 \\
\hline Soybean meal & 30.88 \\
\hline Meat-bone meal & 2.80 \\
\hline Fish meal & 9.58 \\
\hline Dicalcium phosphate* & 0.96 \\
\hline DL-methionine & 0.15 \\
\hline Salt & 0.12 \\
\hline Vitamin premix $* *$ & 0.25 \\
\hline Mineral premix $* * *$ & 0.25 \\
\hline Lysine & 0.17 \\
\hline Choline & 0.22 \\
\hline \multicolumn{2}{|l|}{ Calculated analysis } \\
\hline Crude protein & 23.61 \\
\hline Metabolizable energy, $\mathrm{kcal} / \mathrm{kg}$ & 3066.79 \\
\hline Calcium & 0.89 \\
\hline Phosphorus & 0.67 \\
\hline L-lysine & 1.42 \\
\hline Methionine+cysteine & 0.95 \\
\hline \multicolumn{2}{|l|}{ *Contains $24 \%$ Ca and $17.5 \%$ P. } \\
\hline \multicolumn{2}{|c|}{$\begin{array}{l}\text { **Provided per } \mathrm{kg} \text { of diet: vitamin } \mathrm{A}, 12,000 \mathrm{IU} ; \text { vitamin } \mathrm{D} 3,1,500 \mathrm{IU} \text {; vitamin } \mathrm{E}, 50 \mathrm{IU} \text {; vitamin } \mathrm{K}, 5 \mathrm{mg} ; \text { vitamin } B_{1}, 3 \\
\mathrm{mg} \text {; vitamin } B_{2}, 3 \mathrm{mg} \text {; pyroxidine, } 30 \mathrm{mg} \text {; vitamin } B_{12}, 0.3 \mathrm{mg} \text {; pantothenic acid, } 12 \mathrm{mg} \text {; niacin, } 25 \mathrm{mg} ; \mathrm{D} \text { biotin, } 0.5 \mathrm{mg} \text {; } \\
\text { folic acid, } 1 \mathrm{mg} \text {; choline chloride, } 400 \mathrm{mg} \text {. }\end{array}$} \\
\hline \multicolumn{2}{|c|}{$\begin{array}{l}\text { ***Provided per } \mathrm{kg} \text { of diet: iron, } 80 \mathrm{mg} \text {; zinc, } 40 \mathrm{mg} \text {; manganese, } 60 \mathrm{mg} \text {; iodine, } 0.8 \mathrm{mg} \text {; copper, } 8 \mathrm{mg} \text {; selenium, } 0.2 \\
\mathrm{mg} ; \text { cobalt, } 0.4 \mathrm{mg} \text {. }\end{array}$} \\
\hline
\end{tabular}

Tibia ash percentage determination was performed according to AOAC International (2005), where tibia pieces were collected, defatted, and ashed at $600^{\circ} \mathrm{C}$ for $16 \mathrm{~h}$ to determine ash percentage. Total phosphorus in the samples was determined according to Onyango et al. (2003), using a colorimetric method. Briefly, samples were ashed and boiled in acid to dissolve all phosphorus. The concentration of phosphorus in the supernatant was determined using available kits. Ammonium molybdate was added to the supernatant to form phosphomolybdate, which was then reduced to form a blue phosphomolybdenum complex. Color intensity of the complex was proportional to the phosphorus concentration and was determined with a spectrophotometer using absorption at $620 \mathrm{~nm}$. Calcium was determined by flame atomic absorption spectroscopy.

\section{Microbial count:}

At the end of the experiment, nine birds from each group were slaughtered ( 3 birds from each replicate) and a part of ileum was taken. Total bacterial count, salmonella, E-coli and clostridium were counted in each ileum part using the procedure of AOAC (2005).

\section{Statistical analysis:}

Data were statistically analyzed by one-way analysis of variance for treatment effect, using the general linear model (GLM) procedure of SAS (2006). When the model was significant, Duncan's test (Duncan, 1955 ) was used to separate treatment means at $\mathrm{P}<0.05$. 


\section{RESULTS AND DISCUSSION}

\section{Production performance:}

The performance of Japanese quail under different stoking densities and fed diet supplemented with vitamin E and selenium are represented in Table (2). High stoking density negatively affected body weight gain (BWG) and feed conversion ratio (FCR) compared to the low stoking density at all periods under study. Similar results were obtained in broiler chickens reared under low and high stoking densities with impaired BWG and FCR in the high stoking density group compared to the low stoking density group (Guardia et al., 2011; Zuowei et al., 2011; Houshmand et al., 2012; Tong et al., 2012; El-Gogary et al., 2015). Feddes et al. (2002) reported a reduction in body weight and carcass weight in broilers reared under high stoking density.

On the other hand, different experimental supplementations with vitamin $\mathrm{E}$ and selenium had positive effects on BWG, FCR and feed intake but with different magnitude, being more pronounced for Vit $\mathrm{E}+\mathrm{Se}$ followed by Vit E, Se, the negative control and then the positive control group. On the other hand, feed intake changed significantly, and was the highest for Vit E+Se group and the lowest was for the negative control group at the first and the third periods. The second period showed adverse change in feed intake where the P-Control group had the highest feed intake followed by the Vit E group and Se group and then the Vit E+Se group and finally the N-Control group. Sahin and Kucuk (2001b) reported positive effects of 250 $\mathrm{mg}$ vitamin $\mathrm{E}$ and $0.2 \mathrm{mg}$ selenium supplementation $/ \mathrm{kg}$ diet on final body weight, feed intake and feed conversion to heat stressed quail. In the study of Sahin and Kucuk (2001a), vitamin E supplementation showed a beneficial effect on feed intake, final body weight and feed efficiency when was supplemented to the diet of heat stressed quail.

Table (2): The performance of quail under different stoking densities and fed diet supplemented with vitamin $\mathbf{E}$ and selenium.

\begin{tabular}{lccccc}
\hline Performance & N-Control & P-Control & Vit E & Se & Vit E+Se \\
\hline Initial weight, g & $32.5 \pm 0.31$ & $31.4 \pm 0.30$ & $32.7 \pm 0.32$ & $33.2 \pm 0.25$ & $32.8 \pm 0.27$ \\
Final weight, g & $245.6 \pm 2.44^{\mathrm{c}}$ & $229.4 \pm 2.46^{\mathrm{d}}$ & $262.8 \pm 2.42^{\mathrm{b}}$ & $261.4 \pm 2.57^{\mathrm{b}}$ & $279.7 \pm 2.40^{\mathrm{a}}$ \\
Weight gain, g & & & & & \\
8-21d & $80.1 \pm 1.40^{\mathrm{d}}$ & $72.0 \pm 1.60^{\mathrm{e}}$ & $92.9 \pm 1.43^{\mathrm{b}}$ & $89.6 \pm 1.57^{\mathrm{c}}$ & $101.6 \pm 1.44^{\mathrm{a}}$ \\
22-35d & $108.2 \pm 0.76^{\mathrm{d}}$ & $102.9 \pm 2.04^{\mathrm{e}}$ & $110.8 \pm 2.41^{\mathrm{b}}$ & $108.8 \pm 2.04^{\mathrm{c}}$ & $114.0 \pm 2.29^{\mathrm{a}}$ \\
36-42d & $24.80 \pm 0.39^{\mathrm{d}}$ & $23.07 \pm 2.12^{\mathrm{e}}$ & $26.44 \pm 3.08^{\mathrm{c}}$ & $29.80 \pm 3.07^{\mathrm{b}}$ & $31.22 \pm 2.87^{\mathrm{a}}$ \\
Feed intake, g/d & & & & \\
8-21d & $169.8 \pm 1.43^{\mathrm{e}}$ & $177.1 \pm 1.14^{\mathrm{d}}$ & $211.8 \pm 0.92^{\mathrm{b}}$ & $205.2 \pm 0.85^{\mathrm{c}}$ & $224.5 \pm 0.98^{\mathrm{a}}$ \\
22-35d & $309.5 \pm 1.34^{\mathrm{d}}$ & $351.9 \pm 1.62^{\mathrm{a}}$ & $345.7 \pm 1.28^{\mathrm{b}}$ & $343.8 \pm 1.13^{\mathrm{b}}$ & $337.4 \pm 1.00^{\mathrm{c}}$ \\
36-42d & $84.6 \pm 0.82^{\mathrm{c}}$ & $87.9 \pm 1.75^{\mathrm{c}}$ & $92.7 \pm 0.88^{\mathrm{b}}$ & $105.8 \pm 1.26^{\mathrm{a}}$ & $106.7 \pm 0.85^{\mathrm{a}}$ \\
Feed conversion & & & & & \\
8-21d & $2.12 \pm 0.02^{\mathrm{d}}$ & $2.46 \pm 0.02^{\mathrm{a}}$ & $2.28 \pm 0.01^{\mathrm{b}}$ & $2.29 \pm 0.01^{\mathrm{b}}$ & $2.21 \pm 0.01^{\mathrm{c}}$ \\
22-35d & $2.86 \pm 0.01^{\mathrm{d}}$ & $3.42 \pm 0.02^{\mathrm{a}}$ & $3.12 \pm 0.01^{\mathrm{b}}$ & $3.16 \pm 0.01^{\mathrm{b}}$ & $2.96 \pm 0.01^{\mathrm{c}}$ \\
36-42d & $3.41 \pm 0.03^{\mathrm{b}}$ & $3.81 \pm 0.08^{\mathrm{a}}$ & $3.51 \pm 0.03^{\mathrm{b}}$ & $3.55 \pm 0.041^{\mathrm{b}}$ & $3.42 \pm 0.03^{\mathrm{b}}$ \\
\hline
\end{tabular}

N-Control: negative control, P-Control: positive control.

Means within the same raw having different superscripts differ $(P \varangle 0.05)$.

\section{Blood constituents and tibia composition:}

Blood constituents and tibia ash composition are presented in Table (3). Plasma total protein, albumin, ALT and AST were not differed in different treatments or stoking densities. Although there was a noticeable change in liver enzymes which decreased and plasma total protein and albumin levels which increased due to the supplementation of feed with vitamin $\mathrm{E}$ and selenium compared to the negative and the positive control 
groups. Abudabos et al. (2013a) reported no effect of different stoking densities on broiler blood total protein but AST increased significantly in high stoking density.

Table (3): Blood plasma constituents and tibia ash, calcium and phosphorus of Japanese quail under different stoking density and fed diet supplemented with vitamin $E$ and selenium.

\begin{tabular}{|c|c|c|c|c|c|}
\hline Parameter & N-Control & P-Control & Vit E & $\mathrm{Se}$ & Vit E+Se \\
\hline $\mathrm{TP}, \mathrm{g} / \mathrm{dl}$ & $5.23 \pm 0.19$ & $5.25 \pm 0.15$ & $5.62 \pm 0.15$ & $5.59 \pm 0.15$ & $5.66 \pm 0.15$ \\
\hline $\mathrm{Alb}, \mathrm{g} / \mathrm{dl}$ & $2.64 \pm 0.14$ & $2.67 \pm 0.12$ & $2.91 \pm 0.12$ & $2.89 \pm 0.12$ & $2.98 \pm 0.12$ \\
\hline Chole, $\mathrm{mg} / \mathrm{dl}$ & $147.2 \pm 2.53^{\mathrm{ab}}$ & $149.3 \pm 2.49^{\mathrm{a}}$ & $137.4 \pm 2.89^{c}$ & $139.2 \pm 2.84^{\mathrm{bc}}$ & $136.3 \pm 3.53^{\mathrm{c}}$ \\
\hline $\mathrm{TL}, \mathrm{mg} / \mathrm{dl}$ & $269.5 \pm 5.59^{\mathrm{a}}$ & $265.4 \pm 5.58^{\mathrm{a}}$ & $231.7 \pm 4.03^{\mathrm{b}}$ & $230.6 \pm 4.12^{\mathrm{b}}$ & $229.5 \pm 4.27^{b}$ \\
\hline ALT, U/l & $23.58 \pm 1.14$ & $23.64 \pm 1.03$ & $21.82 \pm 1.06$ & $22.04 \pm 1.15$ & $21.72 \pm 1.06$ \\
\hline $\mathrm{AST}, \mathrm{U} / \mathrm{l}$ & $34.33 \pm 0.92$ & $34.42 \pm 0.97$ & $32.47 \pm 0.89$ & $32.51 \pm 0.84$ & $32.39 \pm 0.65$ \\
\hline $\mathrm{Ca}, \mathrm{mg} / \mathrm{dl}$ & $8.46 \pm 0.22^{\mathrm{a}}$ & $7.41 \pm 0.27^{\mathrm{b}}$ & $8.59 \pm 0.28^{\mathrm{a}}$ & $8.48 \pm 0.26^{\mathrm{a}}$ & $8.76 \pm 0.25^{\mathrm{a}}$ \\
\hline $\mathrm{P}, \mathrm{mg} / \mathrm{dl}$ & $4.96 \pm 0.13^{\mathrm{a}}$ & $4.32 \pm 0.14^{\mathrm{b}}$ & $4.88 \pm 0.17^{\mathrm{a}}$ & $4.76 \pm 0.13^{\mathrm{a}}$ & $4.95 \pm 0.15^{\mathrm{a}}$ \\
\hline Tibia ash, $\%$ & $45.34 \pm 0.47^{\mathrm{c}}$ & $43.64 \pm 0.42^{\mathrm{d}}$ & $49.53 \pm 0.42^{b}$ & $48.63 \pm 0.35^{\mathrm{b}}$ & $51.22 \pm 0.43^{\mathrm{a}}$ \\
\hline Tibia Ca,\% & $12.87 \pm 0.59^{\mathrm{a}}$ & $10.74 \pm 0.56^{\mathrm{b}}$ & $13.83 \pm 0.44^{\mathrm{a}}$ & $13.62 \pm 0.31^{\mathrm{a}}$ & $14.00 \pm 0.25^{\mathrm{a}}$ \\
\hline Tibia P, \% & $8.21 \pm 0.39^{\mathrm{b}}$ & $7.46 \pm 0.36^{\mathrm{b}}$ & $10.00 \pm 0.39^{\mathrm{a}}$ & $9.64 \pm 0.36^{\mathrm{a}}$ & $10.16 \pm 0.28^{\mathrm{a}}$ \\
\hline
\end{tabular}

Means within the same raw having different superscripts differ $(P \triangleleft 0.05)$.

Vitamin E supplementation decreased plasma cholesterol level compared to the negative and positive control groups. Plasma total lipid decreased due to different supplementation treatments. Plasma calcium and phosphorus levels also were significantly increased due to different supplementations compared to positive control group. Houshmand et al. (2012) found no effect of different stoking densities on blood cholesterol level for broiler chickens. Also, serum calcium tended to decrease in laying hens under high stoking rate compared to under the low stoking rate (Kang et al., 2016). The abdominal fat relative weight in broilers reared under cyclic heat stress decreased linearly when selenium was supplemented at the level of $0.1 \mathrm{mg} / \mathrm{kg}$ and vitamin E supplementation level increased from 300 to $500 \mathrm{mg} / \mathrm{kg}$ diet (Albuquerque et al., 2017). This result suggests a modulation in lipid metabolism which could be the reason for the reduction in plasma total lipid and cholesterol observed with these supplementations.

Tibia ash and calcium percentage significantly decreased in the high stoking density control (P-Control) compared to the low stoking density control (N-Control). Vitamin E and selenium supplementations significantly increased tibia ash and phosphorus percentages compared to the P-Control group. Tibia calcium percentage was significantly the highest in the positive control group and was not differed in the different supplementation groups compared to $\mathrm{N}$-Control group. The availability of calcium and phosphorus in the blood pool observed in supplemented groups may explain the significant differences in tibia calcium and phosphorus percentages. Kang et al. (2016) reported significant reduction of bone mineral densities in laying hens under high stoking density.

\section{Microbial count:}

The results of microbial counts in the ileum reveal that counts of salmonella and clostridium microbes did not differ among different groups (Fig. 1). Vitamin E and selenium supplementations and their combination reduced the total bacterial count (TBC) compared to P-Control group and E-coli count compered to N-Control and P-Control groups. The changes in the digestive microbial counts in birds under different stoking densities have been reported by Guardia et al. (2011). They suggested that the changes in the digestive microbiota in high stoking density chickens may be involved in the consequent growth reduction observed. Abudabos et al. (2013b) reported significant increases in ileal Clostridium ( $C$. perfringens) and gram-negative Bacilli counts in the broilers under the high stoking density compared to those under the low stoking density. 


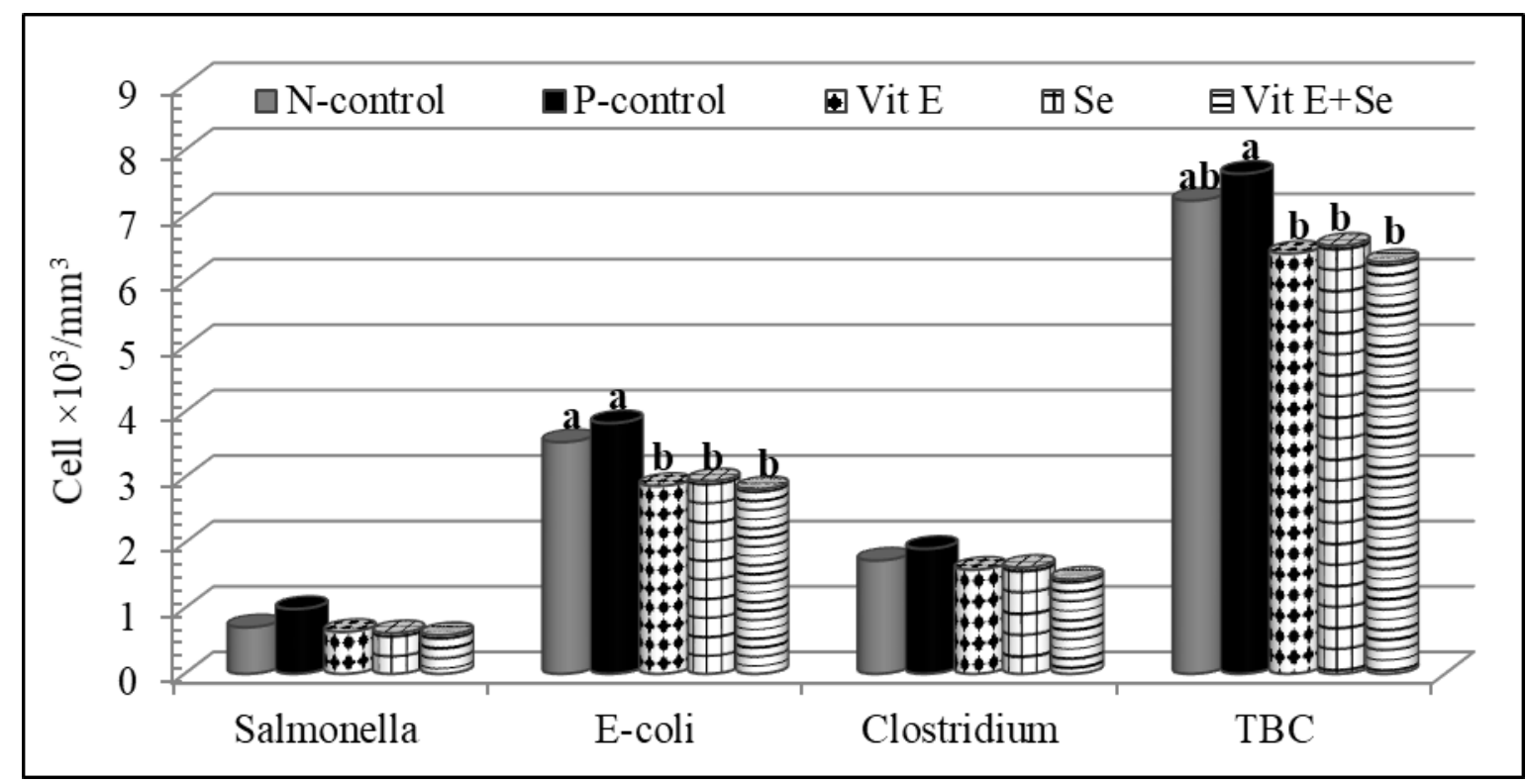

Fig. (1): Different ileum bacterial counts and total bacterial count (TBC) of Japanese quail under different stoking densities and fed diet supplemented with vitamin $\mathrm{E}$ and selenium.

\section{CONCLUSION}

The results revealed that high stoking density impaired quail production performance. Vitamin $\mathrm{E}$ and selenium and their combination supplementation to quail diet can alleviate the negative effects of stoking density and improve the production performance, plasma calcium and phosphorus levels and tibia bone calcium and phosphorus contents. Vitamin $\mathrm{E}$ and selenium supplementation can be a good management practice to improve quail performance under high stoking conditions.

\section{REFERENCES}

Abudabos, A. M.; E. M. Samara; E. O. S. Hussein; M. Q. Al-Ghadi and R. M. Al-Atiyat (2013a). Impacts of Stocking Density on the Performance and Welfare of Broiler Chickens. Italian Journal of Animal Science, 12(1): e11.

Abudabos, A. M.; M. M. Abdelrahman; H. M. Yehia; M. Q. Al-Ghadi and I. A. Alhidary (2013b). Effect of stocking density on intestinal histology and ileal bacterial count in broilers. Asian Journal of Animal and Veterinary Advances, 8: 740-746.

Albuquerque, D. M. N.; J. B. Lopes; M. S. Ferraz; M. N. Ribeiro; S. R. G. Silva; E. M. S. Costa; D. C. P. Lima; J. D. M. Ferreira; P. E. B. Gomes and J. C. O. Lopes (2017). Vitamin E and organic selenium for broilers from 22 to 42 days old: performance and carcass traits. Anais da Academia Brasileira de Ciências, 89(2): 1259-1268.

AOAC International (2005). Official Methods of Analysis of the Association of Official Analytical Chemists. $18^{\text {th }}$ ed. AOAC Int., Arlington, VA. 
Asghar Saki, A.; P. Zamani; M. Rahmati and H. Mahmoudi (2012). The effect of cage density on laying hen performance, egg quality, and excreta minerals. The Journal of Applied Poultry Research, 21(3): 467475.

Attia Y. A.; A. M. Al-Harthi; S. A. El-Shafey; A. Y. Rehab and K. W. Kim (2017). Enhancing tolerance of broiler chickens to heat stress by supplementation with vitamin $\mathrm{E}$, vitamin $\mathrm{C}$ and/or probiotics. Annals of Animal Science, 17(4): 1155-1169.

Avanzo, J. L.; C. X. de Mendonça Jr; S. M. P. Pugine and M. de Cerqueira Cesar (2001). Effect of vitamin $\mathrm{E}$ and selenium on resistance to oxidative stress in chicken superficial pectoralis muscle. Comparative Biochemistry and Physiology Part C: Toxicology and Pharmacology, 129(2): 163-173.

Biswas, A.; J. Mohan and K. V. H. Sastry (2010). Effect of vitamin E on production performance and egg quality traits in Indian native Kadaknath hen. Asian-Aust. Journal of Animal Science, 23(3): 396-400.

Cravener, T. L.; W. B. Roush and M. M. Mashaly (1992). Broiler production under varying population densities. Poultry Science, 71(3): 427-433.

Dozier, I. W. A.; J. P. Thaxton; J. L. Purswell; H. A. Olanrewaju; S. L. Branton and W. B. Roush (2006). Stocking density effects on male broilers grown to 1.8 kilograms of body weight. Poultry Science, $85(2)$ : 344-351.

Duncan, D. B. (1955). Multiple range and multiple F-tests. Biometrics, 11: 1-42.

El-Gogary, M. R.; F. S. A. Ismail and M. I. El-Nadi (2015). Effect of vitamin E supplementation and stocking density on broiler performance, carcass traits and histological responses of lymphoid organs. Asian Journal of Poultry Science, 9: 70-84.

El-Tarabany, M. S. (2016). Impact of cage stocking density on egg laying characteristics and related stress and immunity parameters of Japanese quails in subtropics. Journal of Animal Physiology and Animal Nutrition, 100: 893-901.

EL-Tarabany, M. S.; T. M. Abdel-Hamid and H. H. Mohammed (2015). Effects of cage stocking density on egg quality traits in Japanese quails. Kafkas Üniversitesi Veteriner Fakültesi Dergisi, 21(1): 13-18.

Fan, C., B. Yu and D. Chen (2009). Effects of different sources and levels of selenium on performance, thyroid function and antioxidant status in stressed broiler chickens. International Journal of Poultry Science, 8(6): 583-587.

Feddes, J. J.; E. J. Emmanuel and M. J. Zuidhoft (2002). Broiler performance, body weight variance, feed and water intake, and carcass quality at different stocking densities. Poultry Science, 81(6): 774-779.

Guardia, S.; B. Konsak; S. Combes; F. Levenez; L. Cauquil; J. F. Guillot; C. Moreau-Vauzelle; M. Lessire; H. Juin and I. Gabriel (2011). Effects of stocking density on the growth performance and digestive microbiota of broiler chickens. Poultry Science, 90(9): 1878-1889.

Habibian, M.; G. Sadeghi; S. Ghazi and M. M. Moeini (2015). Selenium as a feed supplement for heatstressed poultry: a review. Biology of Trace Elements Research, 165:183-193.

Harsini, S. G.; M. Habibiyan; M. M. Moeini and A. R. Abdolmohammadi (2012). Effects of dietary selenium, vitamin E, and their combination on growth, serum metabolites, and antioxidant defense system in skeletal muscle of broilers under heat stress. Biology of Trace Element Research, 148: $322-$ 330

Houshmand, M.; K. Azhar; I. Zulkifli; M. H. Bejo and A. Kamyab (2012). Effects of prebiotic, protein level, and stocking density on performance, immunity, and stress indicators of broilers. Poultry Science, 91(2) :393-401.

Jahanian, R. and E. Mirfendereski (2015). Effect of high stocking density on performance, egg quality, and plasma and yolk antioxidant capacity in laying hens supplemented with organic chromium and vitamin C. Livestock Science, 177:117-124. 


\section{Desoky and Kamel}

Kang, H. K.; S. B. Park; S. H. Kim and C. H. Kim (2016). Effects of stock density on the laying performance, blood parameter, corticosterone, litter quality, gas emission and bone mineral density of laying hens in floor pens. Poultry Science, 95(12): 2764-2770.

Mirfendereski, E. and R. Jahanian (2015). Effects of dietary organic chromium and vitamin C supplementation on performance, immune responses, blood metabolites, and stress status of laying hens subjected to high stocking density. Poultry Science, 94(2): 281-288.

Nagarajan, S.; D. Narahari; I. A. Jayaprasad and D. Thyagarajan (1991). Influence of stocking density and layer age on production traits and egg quality in Japanese quail. British Poultry Science, 32(2): 243-248.

Oliveira, T. F. B.; D. F. R. Rivera; F. R. Mesquita; H. Braga; E. M. Ramos and A. G. Bertechini (2014). Effect of different sources and levels of selenium on performance, meat quality, and tissue characteristics of broilers. The Journal of Applied Poultry Research 23(1): 15-22.

Onyango, E. M.; P. Y. Hester; R. Stroshine and O. Adeola (2003). Bone densitometry as an indicator of percentage tibia ash in broiler chicks fed varying dietary calcium and phosphorus levels. Poultry Science, 82(11): 1787-1791.

Qaid, M.; H. Albatshan; T. Shafey; E. Hussein and A. Abudabos (2016). Effect of Stocking Density on the Performance and Immunity of 1- to 14-d- Old Broiler Chicks. Brazilian Journal of Poultry Science, 18(4): 683-692.

Sahin, K. and O. Kucuk (2001a). Effects of vitamin C and vitamin E on performance, digestion of nutrients and carcass characteristics of Japanese quails reared under chronic heat stress $\left(34{ }^{\circ} \mathrm{C}\right)$. Journal of Animal Physiology and Animal Nutrition, 85(11-12): 335-341.

Sahin, K. and O. Kucuk (2001b). Effects of vitamin E and selenium on performance, digestibility of nutrients, and carcass characteristics of Japanese quails reared under heat stress $\left(34^{\circ} \mathrm{C}\right)$. Journal of Animal Physiology and Animal Nutrition, 85(11-12): 342-348.

Sahin, K.; N. Sahin, and M. Onderci (2002). Vitamin E supplementation can alleviate negative effects of heat stress on egg production, egg quality, digestibility of nutrients and egg yolk mineral concentrations of Japanese quails. Research in Veterinary Science 73(3): 307-312.

Sahin, N.; K. Sahin, and M. Onderci (2003). Vitamin E and selenium supplementation to alleviate coldstress-associated deterioration in egg quality and egg Yolk mineral concentrations of Japanese quails. Biological Trace Element Research, 96(1): 179-189.

Sahin, N.; M. Onderci; K. Sahin and O. Kucuk (2008). Supplementation with organic or inorganic selenium in heat-distressed quail. Biological Trace Element Research, 122(3): 229-237.

SAS (2006). SAS/STAT ${ }^{\circledR} 9.1$ User's Guide. SAS Institute Inc., Cary, NC, USA.

Selvam, R.; M. Saravanakumar; S. Suresh; G. Sureshbabu; M. Sasikumar and D. Prashanth (2017). Effect of vitamin $\mathrm{E}$ supplementation and high stocking density on the performance and stress parameters of broilers. Brazilian Journal of Poultry Science, 19(4): 587-594.

Shanawany, M. M. (1988). Broiler performance under high stocking densities. British Poultry Science, 29(1): $43-52$.

Singh, H.; S. Sodhi and R. Kaur (2006). Effects of dietary supplements of selenium, vitamin E or combinations of the two on antibody responses of broilers. British Poultry Science, 47(6): 714-719.

Surai, P.F. (2002). Selenium in poultry nutrition 2. Reproduction, egg and meat quality and practical applications. World's Poultry Science Journal, 58:431-450.

Tong, H. B.; J. Lu; J. M. Zou; Q. Wang and S. R. Shi (2012). Effects of stocking density on growth performance, carcass yield, and immune status of a local chicken breed. Poultry Science, 91: 667-673. 
Vesco, A. P. D.; E. Gasparino; V. Zancanela; D. O. Grieser; C. E. Stanquevis; P. C. Pozza and A. R. O. Neto (2017). Effects of selenium supplementation on the oxidative state of acute heat stress-exposed quails. Journal of Animal Physiology and Animal Nutrition, 101(1): 170-179.

Ziaei, N.; N. M. kor and E. E. Pour (2013). The effects of different levels of vitamin-E and organic selenium on performance and immune response of laying hens. African Journal of Biotechnology, 12(24): 38843890.

Zuowei, S.; L. Yan; L. Yuan; H. Jiao; Z. Song; Y. Guo and H. Lin (2011). Stocking density affects the growth performance of broilers in a sex-dependent fashion. Poultry Science, 90(7): 1406-1415.

\title{
إضافة فيتامين هـ والسيلينيوم إلى العليقة تعمل على تخفيف الأثار السلبية لزيادة الكثافة فى السمان اليابانى النامى
}

\author{
عادل عبد المنعم دسوقى 1 و نانسى نبيل كامل2 2

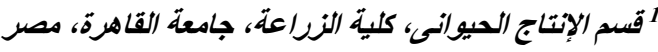

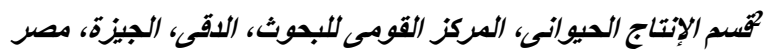

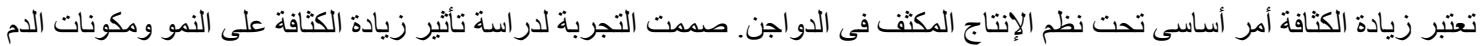

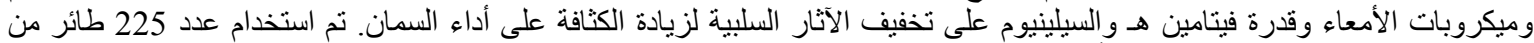

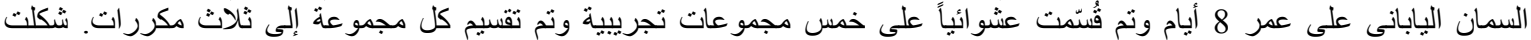

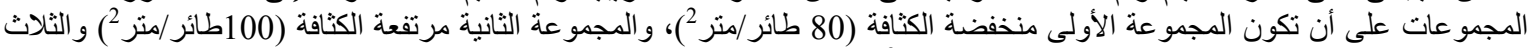

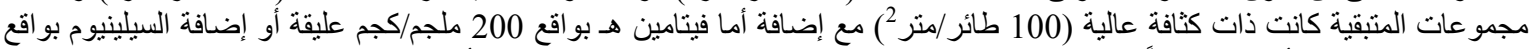

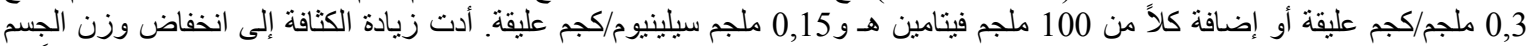

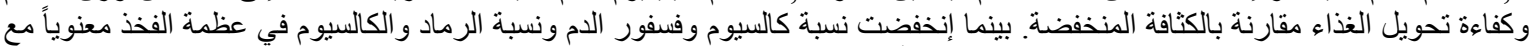

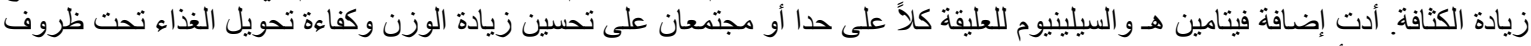

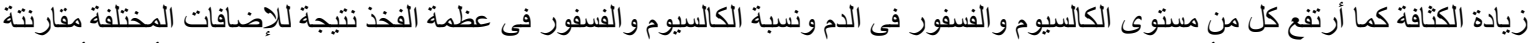

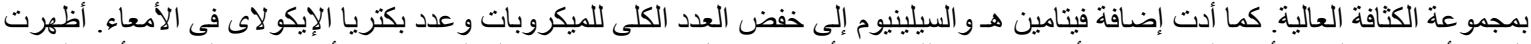

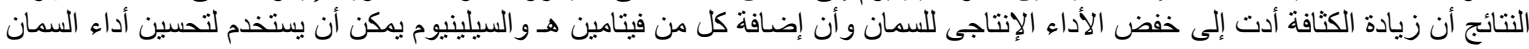
تحت ظروف الإنتاج المكثف. 